\title{
Does coastal lagoon habitat quality affect fish growth rate and their recruitment? Insights from fishing and acoustic surveys
}

\author{
P. Brehmer ${ }^{a, *}$, T. Laugier ${ }^{b}$, J. Kantoussan ${ }^{c}$, F. Galgani ${ }^{d}$, D. Mouillot ${ }^{e}$
}

\author{
a Institut de Recherche pour le Développement, UMR LEMAR (CNRS, UBO, IRD, IFREMER), ISRA/CRODT, Pole \\ de Recherches de Hann, BP 2241, Dakar, Senegal \\ ${ }^{\mathrm{b}}$ Institut Français de Recherche pour l'Exploitation de la MER, RBE/LEAD, Unité de Saint Vincent Ouenghi, BP \\ 2059, 98846 Nouméa Cedex, New Caledonia \\ ${ }^{c}$ Université Gaston Berger, BP 234, Saint-Louis, Senegal \\ d Institut Français de Recherche pour l'Exploitation de la MER, PAC/Corse, Imm. Agostini, ZI Furiani, 20600 \\ Bastia, France \\ e Université de Montpellier 2, UMR ECOSYM (CNRS, UM2, IRD, IFREMER), CC093, 34095 Montpellier Cedex 5, \\ France
}

*: Corresponding author : P. Brehmer, email address : Patrice.Brehmer@ird.fr

\begin{abstract}
:
Ensuring the sustainability of fish resources necessitates understanding their interaction with coastal habitats, which is becoming ever more challenging in the context of ever increasing anthropogenic pressures. The ability of coastal lagoons, exposed to major sources of disturbance, to provide resources and suitable habitats for growth and survival of juvenile fish is especially important. We analysed three lagoons with different ecological statuses and habitat quality on the basis of their eutrophication and ecotoxicity (Trix test) levels. Fish abundances were sampled using fishing and horizontal beaming acoustic surveys with the same protocols in the same year. The relative abundance of Anguilla anguilla, Dicentrarchus labrax or the Mugilidae group was not an indicator of habitat quality, whereas Atherina boyeri and Sparus aurata appeared to be more sensitive to habitat quality. Fish abundance was higher in the two lagoons with high eutrophication and ecotoxicity levels than in the less impacted lagoon, while fish sizes were significantly higher in the two most severely impacted lagoons. This leads us to suggest low habitat quality may increase fish growth rate (by the mean of a cascading effect), but may reduce lagoon juvenile abundance by increasing larval mortality. Such a hypothesis needs to be further validated using greater investigations which take into account more influences on fish growth and recruitment in such variable environments under complex multistressor conditions.
\end{abstract}

Keywords: fish ; shallow water ; ecotoxicity ; lagoon ; habitat quality ; amphidromous 
To be able to evaluate anthropogenic impacts on coastal lagoons we need efficient indicators of their ability to sustain ecosystem functioning and provide ecosystem services upon which human welfare depends such as protein supply. Moreover the European states have to achieve good environmental status of the EU's marine waters by 2020 and to protect the resource base upon which marine-related economic and social activities depend (EC, 2008). However, fishery-environment relationships are complex, and managing shallow water lagoon fisheries remains a difficult task (Breitburg et al., 2009; Brehmer et al., 2011a; PérezRuzafa and Marcos, 2012). Fish have often been used to detect the disruption of marine and coastal ecosystems (e.g. Harmelin, et al., 1995; Ramos Miranda et al., 2005; Villeger et al., 2010), and recently Rose et al. (2009) demonstrated the impact of hypoxia events on fish populations using modelling studies, while Stierhoff et al. (2006) focused on the 'nursery quality' of such critical habitats. More precisely, Stierhoff et al. (2009) used the RNA to DNA ratio to show that hypoxia events induce growth limitation in juvenile flat fishes, similarly as Brown-Peterson (2008) had observed with Palaemonetes pugio in an experimental study.

Since fish abundance has been recognized to be positively linked to the quality of habitats that promotes growth and survival of early life stages (Ross, 2003), the ecological status of estuaries and lagoons, offering food quantity and shelter for the larval and juvenile stages (Whitfield, 1999), is thus crucial to the sustainability of this resource. Indeed, high-quality coastal habitats, beyond their eutrophication and other physico-chemical characteristics, are also those where the abundance of juvenile fish is enhanced and fish growth optimized (Taylor et al., 2007). Using flat fish growth, size, body condition as well as population abundance Gilliers et al. (2006) have assessed that bad habitat quality (chemical contamination) had a negative impact on biological performances.

We carried out a study in three shallow coastal lagoons in the South of France (LanguedocRoussillon) along a gradient of habitat quality. The Languedoc-Roussillon lagoons occupy a total area of 40,000 ha, often exploited by small scale fisheries. Leaving aside recreational angling, the commercial fish catch amounts to about 2,000 metric tonnes per year (Guillou et al., 2002), with a total of 532 small fishing boats working in the regional lagoons. Mediterranean lagoons of this kind serve as critical nursery areas for many fish among which some are commercially important species such as Sparus aurata (Beck et al., 2001; Mercier et al., 2011). In a previous study, fishing surveys were performed to investigate fish abundances: initial findings suggested that the eutrophication level had no impact on fish diversity, even if an evidence of an impact on macrozoobenthic diversity was reported (Mouillot et al., 2005). We also assessed diagnostic estimators of the eutrophication level and ecotoxicity (Brehmer et al., 2006; 2011a) for these lagoons. Here, an acoustic method was used to provide further information about pelagic fish characteristics; individual fish were detected using a fixed split-beam echo-sounder (e.g. Kubecka and Duncan, 1998a) with horizontal beaming. This paper used data from both fishing and horizontal beaming acoustics surveys to investigate the relationship between habitat quality, define in this work as the lagoon ecological status and toxicological effect of pesticides, and the abundance and size of lagoon fish.

\section{Material and methods}

\subsection{Three shallow water lagoons and their habitat characteristics}

Three Mediterranean lagoons (characterised by low tide amplitudes and a temperate climate) were studied (Fig. 1). They are located less than $19 \mathrm{~km}$ from each other along the same 
coast. The Or lagoon (Carnon-Pérols-Mauguio) has a total surface area of 3,167 ha. (average depth: $0.8 \mathrm{~m}$ ), the Prévost lagoon (Palavas-les-flots) has an area of 380 ha. (average depth: $0.3 \mathrm{~m}$ ), and the Ingril lagoon (Frontignan) has an area of 549 ha. (average depth: $0.6 \mathrm{~m})$.

(Fig. 1. Here)

Differences in habitat quality were assessed by combining indicators for five compartments: the water column, phytoplankton, macrophyte, biological potentiality and sediment (Brehmer et al. 2011a). In 1999, the Or lagoon has undergone degradation due to the input of poorquality fresh water from its watershed (Fig. 1): its habitat status is bad (high level of eutrophication), as is that of the Prévost lagoon, but the latter has better water column status (Brehmer et al., 2011a). In contrast, the Ingril lagoon has better habitat status (medium level of eutrophication) (Brehmer et al., 2011a). Complementary TRIX tests (Vollenweider, 1998; Giovanardi and Vollenweider, 2004), based mainly on chlorophyll-a concentration and oxygen saturation, have been carried out on the Or and Prevost lagoons from 25 September 1998 to 9 September 1999 (Fig. 2), and have confirmed the difference in habitat status between these two lagoons, with eutrophication having less impact on the Ingril lagoon than on the Or lagoon.

$$
\text { TRIX }=\frac{\left(\log 10\left[\text { Chla } \times \mathrm{aD} \% \mathrm{O} \times \mathrm{N}_{2} \times \mathrm{TP}\right]+\mathrm{k}\right)}{\mathrm{m}}
$$

With Chla $=$ chlorophyll-a concentration $\left(\mu \mathrm{g} \mathrm{I}^{-1}\right) ; \mathrm{aD} \% \mathrm{O}=$ Oxygen as absolute percentage deviation from saturation; $\mathrm{N}_{2}=$ mineral nitrogen: dissolved inorganic nitrogen, DIN $=\mathrm{N}(\mathrm{N}-$ $\left.\mathrm{NO}_{3}+\mathrm{N}-\mathrm{NO}_{2}+\mathrm{N}-\mathrm{NH}_{4}\right)$, in $\mu \mathrm{g} \mathrm{I}^{-1}$; $\mathrm{TP}=$ total phosphorus, $\left(\mu \mathrm{gl}^{-1}\right)$. The parameters $\mathrm{k}=1.5$ and $\mathrm{m}$ $=12 / 10=1.2$, are scale coefficients, introduced to fix the lower limit value of the Index and the extension of the related Trophic Scale, from 0 to 10 TRIX units.

(Fig. 2. Here)

Lastly, ecotoxicological studies have already shown that the impact of pesticides was also greater in the Or and Prévost lagoons than in the Ingril lagoon (Brehmer et al., 2011a). This was shown using acetylcholinesterase activity (which is reduced by neurotoxic compounds, such as organophosphorous compounds) as a specific biomarker..

\subsection{Fishing survey and species abundances}

Some of the data used were reported in previous publications by Mouillot et al. (2005) and Brehmer et al. (2006; 2011a). The fishing survey was carried out using the same fishing gear as that used by local fishermen (capechade) in 1999, with a total of 580 operations (Or: 180; Ingril: 120; Prévost: 280).

The Catch Per Unit of Effort unit, CPUE, was calculated for each species in kg per day (Marr, 1953; Mouillot et al., 2005). We focused on the five most important species i.e. the most abundant in the studied lagoon which were: Dicentrarchus labrax, Sparus aurata, Anguilla anguilla, the group of Mugilidae (i.e. Mugil cephalus, Liza ramada and Liza aurata), and Atherina boyeri (Crepsi, 2002; Brehmer et al., 2006). 


\subsection{In situ lagoon fish sampling using horizontal beaming acoustics}

We have used a mobile laboratory set on a camping car with independent power block to carry out acoustic surveys. This system allowed reaching each lagoon monitoring spot (lagoon channel to the sea) with 2-4 hours delay between each other. A split beam echosounder (Simrad EY 500; $70 \mathrm{kHz}$ ) was used with horizontal beaming across the lagoon channel (Brehmer et al., 2006; 2011a); this was able to detect individual fish by measuring their Target Strength (TS) values (Gonzalez and Gerlotto, 1998; Kubecka and Wittingerova, 1998ab; Boswell et al., 2007). The Time Varied Gain (TVG) function was 40 Log R, and the pulse length $0.1 \mathrm{~ms}$. The echosounder had a single $8.6^{\circ} * 4.2^{\circ}$ beam split (elliptical transducer type: SIMRAD ES 120-4.10). The echosounder data were stored in files of 15 minutes; the threshold used was $-65 \mathrm{~dB}$. The post-processing sampling procedure consisted of deleting any series of data corrupted by the passage of boat or silt resuspension. After doing this, 15 minutes of data per hour was selected for post-processing.

The parameters used for the echosounder data analysis were chosen to validate fish detection i.e. four pings recognized a detection as being a fish, the minimum distance between two targets was $30 \mathrm{~cm}$, the dynamic tracking of one target allowed one ping to be missed, and we used the EP500 software (Lindem and Al Houari, 1993). There was a relationship between the size and TS of fish (Love 1977; McClatchie et al., 1996; Guillard et al., 2004) provided by the echosounder data. The TS variability of fish mainly depends on size, species and depth, but also on the orientation of individuals within the acoustic beam, and its physiological condition (Ona, 1999). In this study, our methodology did not enable to identify fish species, and so the conversion of TS values into fish sizes has to be considered unreliable (Knudsen and Sægrov, 2002). Nevertheless, as the fish diversity was the same in these three lagoons (Mouillot et al. 2005), and the fact that the sampling method used and fish depth were identical, we were able to use the TS values to indicate the relative fish size spectra (e.g. from $1 \mathrm{~cm}$ for a TS of $-65 \mathrm{~dB}$ to a maximum of $30 \mathrm{~cm}$ for TS values of $-35 \mathrm{~dB}$ using the Love (1977) conversion equation). The fish TS distributions in lagoon channels were obtained by monitoring the same spot three times $24 \mathrm{~h} 00$ on a step time of one month during autumn (1999), which had been identified as a migration (lagoon toward the sea) period (Brehmer et al., 2006).

\subsection{Dataset analysis}

The fishing and acoustic data were not collected simultaneously on each lagoon, i.e. all along the year for the fishing survey and during the annual autumnal lagoon fish migration toward the Sea for the acoustic data. The fishing data were used to compare the relative abundance between lagoons and to rank each species in each lagoon using a same methodology and same fishing gear. The acoustic values extracted from the investigation carried out for the 'Or' and 'Prévost' lagoon, classified as BHS (see previous paragraph 2.1) were compared to those obtained for the 'Ingril' lagoon classified as GHS, using an Test $U$ of Mann-Whitney for the fish TS values. In this study we distinguished between the Or and Prevsot lagoons which had bad health status 'BHS' (see paragraph 2.2 and 2.3) and the Ingril lagoon, which was classified as having good health status 'GHS' (see paragraph 2.2 and 2.3). 


\section{Results}

We estimated CPUE values of 543 and $932 \mathrm{~kg}$ per day for the Or and Prévost lagoons, respectively. Overall, we thus obtained a mean CPUE of $737 \mathrm{~kg}$ per day for the BHS lagoons, which was almost twice the value found in the Ingril GHS lagoon, i.e. $405 \mathrm{~kg}$ per day. Eels $(A$. anguilla) constituted the bulk of the fish caught; their relative abundance was lowest in the GHS lagoon (Fig. 3). The Mugilidae group was the second most abundant after $A$. anguilla. They were present in all three lagoons sampled. In a decreasing rank of relative abundance we found that $A$. boyeri and $S$. aurata were present in all three lagoons. We observed that the relative abundances of $A$. boyeri were particularly low in the Ingril GHS lagoon while high in the 'Or' Lagoon. S. aurata was the least abundant species in the BHS lagoons, while it was most abundant in the GHS lagoon and almost absent in Prevost. $D$. labrax, the third most abundant fish species overall in the lagoons, was in fact not caught in the 'Or' BHS lagoon and was more present in the 'Prévost' lagoon like the Mugilidae.

(Fig. 3. Here)

From the acoustic data we estimated a total number of fish individuals detected at 93841, with an average Target Strength ' $\overline{T S}$ ' $=-51.92$ (standard deviation ' $\sigma$ ' $=4.24$ ) distributed in $22364,37,765$ and 33712 targets, for the 'BHS ${ }_{\text {Or' }}(\bar{T} \bar{S}=-52.08 ; \sigma=4.40)$, BHS Prévost $(\overline{T S}=-$ 51.36; $\sigma=4.17)$ and 'GHS Ingril' $(\overline{T S}=-52.44 ; \sigma=4.12)$ lagoons respectively (Fig. 4a). There was a significant difference $(p<0.05)$ between the distributions of relative pelagic fish sizes (TS) according to the habitat quality (Fig. 4b). The GHS lagoon had lower TS values ( $p<$ 0.05) than the two BHS lagoons.

(Fig. 4. Here)

\section{Discussion}

Classical acoustic assessment methods (Simmonds and MacLennnan, 2005) are not suitable for use in very shallow water, both for logistic reasons due to water shallowness, and biological reasons, because of the obvious fish avoidance reaction to the approaching boat (Kubecka and Wittingerova, 1998; Guillard et al., 2010). However, direct horizontal beaming acoustic observations in situ of fish population characteristics in very shallow lagoons (less than 1 meter depth) have been shown to be useful in several kinds of studies with, e.g. ecological (Brehmer et al., 2006), management (Brehmer et al., 2011a), and behavioural goals (Brehmer et al., 2011b). In this work, the relative size of lagoon fish obtained with an acoustic method were complementary to fishing data (Brehmer et al., 2006), and combining these two types of information added to our knowledge about fish abundance in lagoons. Hydroacoustic samples recorded at a fixed station can serve as a proxy of the catches from a purse seine and can allow the monitoring of fish biomass in estuaries (Guillard et al. 2012). Moreover acoustic observations can be made independently of intrusive fishing operations and are not constrained by the limits of visual observation methods (Brehmer, 2006). According to Brehmer et al. (2006) the fish detected by the sonar during acoustic surveys carried out in this study are mainly $D$. labrax, $S$. aurata, A. boyeri or one of the three Mugilidae species, which are the most abundant fish species in the shallow water lagoons of this region (Mouillot et al., 2005). To obtain accurate fishery data in coastal lagoon is not 
simple (see Pérez-Ruzafa and Marcos, 2012). Moreover the biological sampling by fishing, using a single gear, is selective with regard to fish species and size (Franco et al., 2011), i.e. the study does not target all fish species, but only a part of the fork-length distribution of those caught, especially in shallow water environment and using the local, small-scale fishing gear (Bach et al., 1992; Crepsi, 2002). Thus, this selectivity of fishing gear (MacLennan, 1994) biases the absolute diversity, size spectra and abundance in the lagoons (Franco et al., 2011; Guillard et al. 2012). Nevertheless, using the same sampling method does make it possible to compare the different lagoons since the bias remains consistent. Abundances of $A$. anguilla and $A$. boyeri were found to be higher in the BHS lagoons, i.e. in the lagoons with high eutrophication and ecotoxicity levels. In contrast, $S$. aurata appeared to be more abundant in the GHS lagoon.

The effect of habitat quality on fish population characteristics can vary depending on the feeding, spawning and migratory behaviour of the fish present. Fish size is related to metabolic rate and energy assimilation, both of which are species dependent; nevertheless inter-specific differences can also be due to differences in foraging efficiency (Mittelbach, 1981) and habitat quality (Phelan et al., 2000). The BHS lagoons (Or and Prevost) have higher phytoplankton productivity (Fig. 1 and 2), which may explain why fish abundance in these lagoons was higher than that in the GHS lagoon (Ingril). Habitat quality can also play a significant role in the size structure of a lagoon fish population. In marine environments, Shin et al. (2005) used this indicator to investigate the exploitation of fish stocks by the fishing industry. Fish richness (number of species) is known to be similar in the three lagoons of our case study as reported by Mouillot et al., (2005). Consequently we can assume that differences in TS values therefore reflect an effect of habitat quality on lagoon fish size spectra. Indeed if fish species composition was different it would be not possible to compare fish populations, i.e. BHS and GHS lagoons, as the intensity of acoustic responses is species dependant, independently from fish size (Simmonds and MacLennan, 2005).

Coastal lagoon fish populations consist mainly of juveniles (Beck et al., 2001); the smaller one cannot be selected by our fishing gear, but only by our acoustic system. Juveniles prefer shallow and calm waters, where they are likely to find food and where there are fewer predators (Blaber and Blaber, 1980), and the water in all the studied lagoons was calm and shallow. The $\mathrm{GHS}_{\text {Ingril }}$ lagoon had the lowest relative fish size derived from TS values. This lagoon hosts eelgrass stands, which protect the juveniles against predators (Blaber and Blaber, 1980). Conversely, the BHS lagoons do not contain such eelgrass areas, as they are affected to a greater extent by eutrophication and the presence of pesticides (see, Souchu et al., 2010; Bec et al. 2011; Brehmer et al., 2011a).

The fish size distribution derived from acoustic observation reflects the growth rate and the importance of juveniles in the lagoons. Contaminant levels could impact the efficiency of fish reproduction and recruitment by increasing larval mortality or decreasing egg production of species spawning inside the lagoon i.e. A. boyeri (Tomasini and Laugier, 2002). Scott and Sloman (2004) have shown that the potential effect of environmental pollutants on reproductive behaviour may disrupt mate selection, successful fertilization, or the survival of the offspring in a natural setting; all of which are key aspects of recruitment success. On demersal fish it was observed that estuaries nursery areas could be impacted by the levels of contamination inducing a decrease of fish growth performances and density (Guillier et al., 2006). Previous studies, carry out in the same lagoons studied in this work, investigating the quality of sediment by means of a larval bio test (Brehmer et al., 2011a) have clearly demonstrated the potential impact of contaminants on larval development and on the recruitment of aquatic organisms in these lagoons. Nevertheless without knowledge on the homing behaviour of the lagoon fish spawning in open sea (S. aurata, A. Anguilla, D. labrax and Mugilidae), we cannot conclude to a clear assumption on the effect of pesticide on lagoon fish. However it appears that the lagoon fish abundance was higher for the BHS vs. GHS lagoons. GHS foster the low trophic level production and thus the fish compartment by 
a cascading effect (Carpenter et al., 1985) in absence of hypoxia event. Moreover in GHS the eelgrass stands protect the juveniles against predators and thus may limit the availability of prey for lagoon piscivorous fish (e.g. A. Anguilla, D. Labrax). Obviously numerous other factors can influence recruitment and fish growth (Beck et al. 2001; Gillier et al. 2006). Deeper investigations integrating different spatio-temporal scale, are thus necessary before providing any definitive conclusion. Gillier et al. (2006) underline that the loss of adaptative capacity may reduce the metabolic scope of fishes and thus the fish growth and population size in altered habitats.

In the present study, it would appear that anthropogenic effects, reflected by an increase in eutrophication and pesticide inputs into the shallow water lagoon ecosystems, might influence fish resources at two levels. First, the most severely degraded lagoons appear to be the most productive. Second, lagoon fish recruitment could be suspected of being linked to the level of eutrophication and to the level of pesticides inputs, with good status promoting recruitment. Additional studies about the temporal and spatial patterns of species composition (Perez-Ruzafa et al., 2004) and about the abundance of fish larvae and juveniles (Tzeng and Wang, 1992) are required to confirm the effect of anthropogenic activities on fish populations. Future studies should divide fishes into functional groups (Villeger et al., 2010), and then investigate the characteristics and relative dynamics (abundance, diversity and size spectra) of these different groups with respect to the quality of their respective habitats.

\section{Acknowledgements}

This study was funded by a grant provided by the Languedoc-Roussillon Region and the French state CPER XI coordinate by Prof. Thang Do $\mathrm{Chi}^{\dagger}$ (UMR ECOSYM) to who we dedicated this works. Additional data were provided by Ifremer observatory network (LERLR, Sète). The final analysis was funded by the GIS Europole Mer (Plouzané, France), the AWA (BMBF-AIRD) project and done inside the Labex Mer. We would like to thank Prof. Andrew Bakun (University of Miami) for his early encouragement and the anonymous referees for their constructive comments and corrections.

\section{References}

Bach, P., Legendre, P., Amanieu, M., Lasserre, G., 1992. Strategy of Eel (Anguilla-Anguilla L) Exploitation in the Thau Lagoon. Estuarine Coastal and Shelf Science 35, 55-73.

Bec, B., Collos, Y., Souchu, P., Vaquer, A., Lautier, J., Fiandrino, A., Benau, L., Orsoni, V., Laugier, T., 2011 Distribution of picophytoplankton and nanophytoplankton along an anthropogenic eutrophication gradient in French Mediterranean coastal lagoons. Aquatic Microbial Ecology 63, 29-45.

Beck, M.W. et al., 2001. The identification, conservation, and management of estuarine and marine nurseries for fish and invertebrates. Bioscience 51, 633-641.

Blaber, S.J.M., Blaber, T.G., 1980. Factors affecting the distribution of juvenile estuarine and inshore fish. Journal of Fish Biology 17, 143-162.

Brehmer, P., Mouillot, D., Do Chi, T., 2006. Amphidromus fish school diel flow in two Mediterranean lagoons by combining sonar and fishing data. Journal of Experimental Marine Biology and Ecology 334, 139-150.

Brehmer, P., 2006. Fisheries Acoustics: Theory and Practice, 2nd edn. Fish and fisheries 7, 227-228. 
Brehmer, P., Do Chi, T., Laugier, T., Galgani, F., Laloë, F., Darnaude, A. M., Fiandrino, A., Mouillot, D., 2011a. Field investigations and multi-indicators for shallow water lagoon management: perspective for societal benefit. Aquatic Conservation: Marine and Freshwater Ecosystems 21, 728-742.

Brehmer, P., Guillard, J., Caballero Pinzon, P.I., Bach, P., 2011b. Amphidromous Fish School Exploratory and Instantaneous 1 Swimming Speeds in Shallow Water Coastal Lagoon Channels. Estuaries and Coasts 34, 739-744.

Breitburg, D.L., Craig, J.K., Fulford, R.S., Rose, K.A., Boynton, W.R., Brady, D.C., Ciotti, B.J., Diaz, R.J., Friedland, K.D., Hagy III, J.D., Hart, D.R., Hines, A.H., Houde, E.D., Kolesar, S.E., Nixon, S.W., Rice, J. A., Secor, D.H., Targett, T.E., 2009. Nutrient enrichment and fisheries exploitation: interactive effects on estuarine living resources and their management. Hydrobiologia 629, 31-47.

Brown-Peterson, N.J., Manning, C.S., Patel, V., Denslow, N.D., Brouwer, M., 2008. Effects of Cyclic Hypoxia on Gene Expression and Reproduction in a Grass Shrimp, Palaemonetes pugio. The Biology Bulletin 214, 6-16.

Carpenter, S.R., Kitchell, J.F., Hodgson, J.R., 1985. Cascading Trophic Interactions and Lake Productivity. BioScience 35, 634-639.

Crespi, V., 2002. Recent evolution of the fishing exploitation in the Thau lagoon, France. Fisheries Management and Ecology 9, 19-29.

EC, 2008. Directive 2008/56/EC of the European Parliament and of the Council of 17th June 2008 establishing a framework for community action in the field of marine environmental policy (Marine Strategy Framework Directive). Official Journal of the European Union L 164, 19-36.

Franco, A., Pérez-Ruzafa, A., Drouineau, H., Franzoi, P., Koutrakis, E.T., Lepage, M., Verdiell-Cubedo, D., Bouchoucha, M., López-Capel, A., Riccato, F., Sapounidis, A., Marcos, C., Oliva-Paterna, F.J., Torralva-Forero, M., Torricelli, P., 2011. Assessment of fish assemblages in coastal lagoon habitats: Effect of sampling method. Estuarine, Coastal and Shelf Science, In Press.

Gilliers, C., Le Pape, O., Désaunay, Y., Morin, J., Guérault, D., Amara, R., 2006. Are Growth and density quantitative indicators of essential fish habitat quality? An application to the common sole Solea solea nursery grounds. Estuarine, Coastal and Shelf Science 69, 96106.

Giovanardi, F., Vollenweider, R.A., 2004. Trophic conditions of marine coastal waters: experience in applying the Trophic Index TRIX to two areas of the Adriatic and Tyrrhenian seas. Journal of Limnology 63, 199-218.

Gonzalez, L., Gerlotto, F., 1998. Observation of fish migration between the sea and a mediterranean lagoon (Etang de l'Or, France) using multibeam sonar and split beam echo sounder. Fisheries Research 35, 15-22.

Guillard, J., Lebourges-Dhaussy, A., Brehmer, P., 2004. Simultaneous Sv and TS measurements on Young-of-the-Year (YOY) freshwater fish using three frequencies. ICES Journal of Marine Science 61, 267-273.

Guillard, J., Balay, P., Colon, M., Brehmer, P., 2010. Survey boat effect on Y-O-Y fish schools in a pre-alpine lake: evidence from multibeam sonar and split-beam echosounder data. Ecology of Freshwater Fish 19, 373-380.

Guillard, J., Simier, M., Albaret, J.-J., Raffray, J., Sow, I., Tito de Morais, L., 2012. Fish biomass estimates along estuaries: A comparison of vertical acoustic sampling at fixed stations and purse seine catches. Estuarine, Coastal and Shelf Science 107,105-111.

Guillou, A., Lespagnol, P., Ruchon, F., 2002. La pêche aux petits métiers en LanguedocRoussillion en 2000-2001. http://archimer.ifremer.fr/doc/00000/2286/. DIRAM-IFREMER $\mathrm{N}^{\circ}$ 00/3210040/YF. Ifremer, Sète, $108 \mathrm{pp}$.

Hajisamae, S., Chou, L. M., 2001. Do shallow water habitats of an impacted coastal strait serve as nursery grounds for fish? Estuarine Coastal and Shelf Science 56, 281-290.

Harmelin, J.G., Bachet, F., Garcia, F., 1995. Mediterranean marine reserves: fish indices as tests of protection efficiency. PSZN I: Marine Ecology 16, 233-250. 
Knudsen, F.R., Sægrov, H., 2002. Benefits from horizontal beaming during acoustic survey: application to three Norwegian lakes. Fisheries Research 56, 205-211.

Kubecka, J., Duncan, A., 1998a. Acoustic size versus real size relationships for common species of riverine fish. Fisheries Research 35, 115-125.

Kubecka, J., Wittingerova, M., 1998b. Horizontal beaming as a crucial component of acoustic fish stock assessment in freshwater reservoirs. Fisheries Research 35, 99-106.

Lindem, T., Al Houari, D., 1993. EP500 - A system for processing and presentation of echogram data produced by the SIMRAD EY500/EK500 echo sounders. ICES document C.M. 1993/B. ICES, Copenhagen, 6 pp.

Love, R.H., 1977. Target strength of an individual fish at any aspect. Journal of the Acoustical Society of America 62, 1397-1403.

MacLennan, D.N., 1994. Fishing gear selectivity: an overview. Fisheries Research 13, 201204.

Marr, J.C., 1953. On the use of the terms abundance, availability, and apparent abundance in fishery biology. Copeia 2, 331-334.

McClatchie, S., Alsop, J., Coombs, R.F., 1996. A re-evaluation of relationships between fish size, acoustic frequency, and target strength. ICES Journal of Marine Science 53, 780791.

Mercier, L., Panfili, J., Paillon, C., N'Diaye, A., Mouillot, D., Darnaude, A.M., 2011. Otolith reading and multi-model inference for improved estimation of age and growth in the gilthead seabream Sparus aurata (L.). Estuarine Coastal and Shelf Science 92, 534-545.

Mittelbach, G.G., 1981. Foraging Efficiency and Body Size: A Study of Optimal Diet and Habitat Use by Bluegills. Ecology 62, 1370-1386.

Mouillot, D., Laune, J., Tomasini, J.A., Aliaume, C., Brehmer, P., Dutrieux, E., Chi, T.D., 2005. Assessment of coastal lagoon quality with taxonomic diversity indices of fish, zoobenthos and macrophyte communities. Hydrobiologia 550, 121-130.

Ona E., 1999. Methodology for target-strength measurements. 1999. ICES Cooperative Research Report, 235. ICES, Copenhagen, 59 pp.

Perez-Ruzafa, A., Quispe-Becerra, J.I., Garcia-Charton, J.A., Marcos, C., 2004. Composition, structure and distribution of the ichthyoplankton in a Mediterranean coastal lagoon. Journal of Fish Biology 64, 202-218.

Pérez-Ruzafa, A.,Marcos, C., 2012. Fisheries in coastal lagoons: An assumed but poorly researched aspect of the ecology and functioning of coastal lagoons. Estuarine, Coastal and Shelf Science, In Press.

Phelan, B.A., Goldberg, R., Bejda, A.J., Pereira, J., Hagan, S., Clark, P., Studholme, A.L., Calabrese, A., Able, K.W., 2000. Estuarine and habitat-related differences in growth rates of young-of-the-year winter flounder (Pseudopleuronectes americanus) and tautog (Tautoga onitis) in three northeastern US. Journal of Experimental Marine Biology and Ecology 247, 1-28.

Ramos Miranda, J., Mouillot, D., Flores Hernandez, D., Sosa Lopez, A., Do Chi, T., Ayala Perez, L., 2005. Changes in four complementary facets of fish diversity in a tropical coastal lagoon after 18 years: a functional interpretation. Marine Ecology Progress Series 304, 1-13.

Rose, K.A., Adamack, A.T., Murphy, C.A., Sable, S.E., Kolesar S.E., Craig J.K., Breitburg D.L., Thomas P., Brouwer M. H., Cerco, C.F., Diamond, S., 2009. Does hypoxia have population-level effects on coastal fish? Musings from the virtual world. Journal of Experimental Marine Biology and Ecology 381, 188-203.

Ross, S.W., 2003. The relative value of different estuarine nursery areas in North Carolina for transient juvenile marine fishes. Fishery Bulletin 101, 384-404.

Scott, G.R.,, Sloman, K.A., 2004. The effects of environmental pollutants on complex fish behaviour: integrating behavioural and physiological indicators of toxicity. Aquatic Toxicology 68, 369-392.

Shin, Y.J., Rochet, M.J., Jenning, S., Field, J.G., Gislason, H., 2005. Using size-based indicators to evaluate the ecosystem effects of fishing. ICES Journal of Marine Science 62, 384-396. 
Simmonds, E.J., MacLennan, D.N., 2005. Fisheries acoustics theories and practices, $2^{\text {nd }}$ edition. Chapman \& Hall, Fish and Fisheries serie 5, London.

Souchu, P., Bec B., Smith, V.H., Laugier, T., Fiandrino, A., Benau, L., Orsoni, V., Collos, Y., Vaquer, A., 2010. Patterns in nutrient limitation and chlorophyll a along an anthropogenic eutrophication gradient in French Mediterranean coastal lagoons. Canadian Journal of Fisheries and Aquatic Sciences 67, 743-753.

Stierhoff, K.L., Targett, T.E., Miller, K.L., 2006. Ecophysiological responses of juvenile summer and winter flounder to hypoxia: experimental and modelling analyses of effects on estuarine nursery quality. Marine Ecology Progress Series 325, 255-266.

Stierhoff, K.L., Targett, T.E., Power, J.H., 2009. Hypoxia-induced growth limitation of juvenile fishes in an estuarine nursery: assessment of small-scale temporal dynamics using RNA: DNA. Canadian Journal of Fisheries and Aquatic Sciences 66, 1033-1047.

Taylor, D.L., Nichols, R.S., Able, K.W., 2007. Habitat selection and quality for multiple cohorts of young-of-the-year bluefish (Pomatomus saltatrix): Comparisons between estuarine and ocean beaches in southern New Jersey. Estuarine Coastal and Shelf Science 73, 667-679.

Tomasini, J.A., Laugier, T., 2002. Male reproductive strategy and reserve allocation in sand smelt from brackish lagoons of southern France. Journal of Fish Biology 60, 521-531.

Tzeng, W.N., Wang, Y.T., 1992. Structure, composition and seasonal dynamics of the larval and juvenile fish community in the mangrove estuary of Tanshui River, Taiwan. Marine Biology 113, 481-490.

Villeger, S., Miranda, J.R., Hernandez, D.F., Mouillot, D., 2010. Contrasting changes in taxonomic vs. functional diversity of tropical fish communities after habitat degradation. Ecological Applications 20, 1512-1522.

Vollenweider, R.A., Giovanardi, F., Montanari, G., Rinaldi, A., 1998. Characterization of the trophic conditions of marine coastal waters, with special reference to the NW Adriatic Sea: proposal for a trophic scale, turbidity and generalized water quality index. Environmetrics 9, 329-357.

Whitfield, A.K., 1999. Ichthyofaunal assemblages in estuaries: A South African case study. Reviews in Fish Biology and Fisheries 9, 151-186. 


\section{Figures}

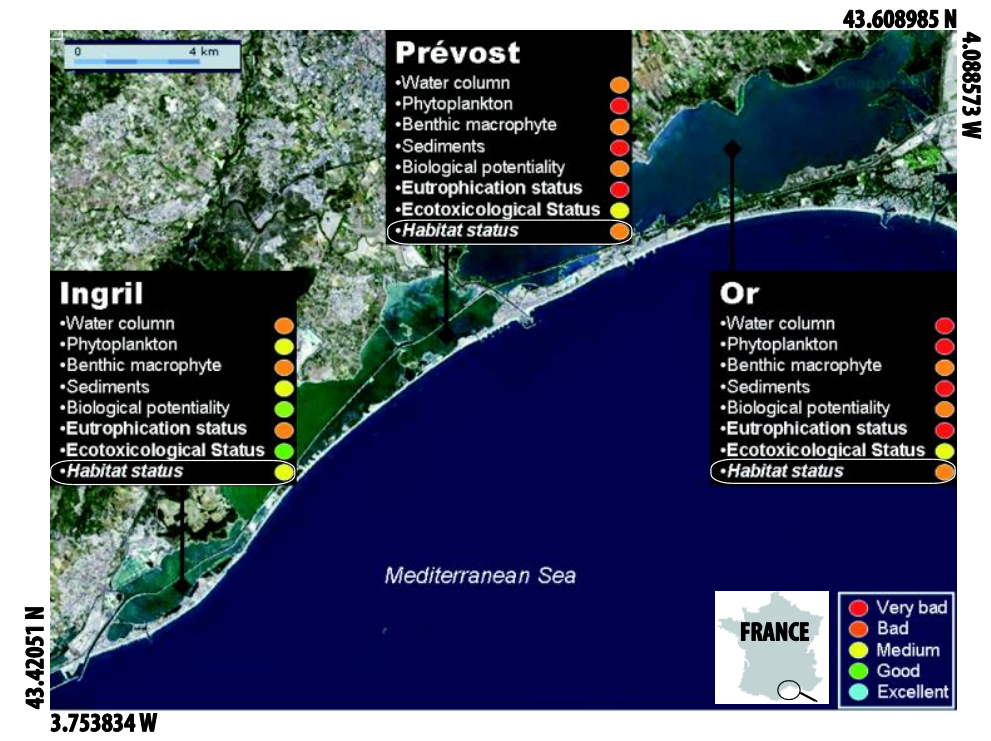

Fig. 1. Map of the three lagoons monitored during the 1999 surveys. The colour codes present the results for each lagoon with their associated eutrophication status (5 main compartments) and Ecotoxicological status (using an acetylcholinesterase biomarker). The diagnostic indicator ranks the lagoons in increasing order of eutrophication with five modalities: the 'Or' and 'Prévost' lagoons were highly eutrophicated, whereas Ingril was less eutrophicated. The ecotoxicity levels of 'Ingril' and 'Or' lagoons were similar, whereas that in 'Prevost' was lower. Finally, we ranked the three lagoon ecosystems in terms of their 'habitat quality' by averaging their eutrophication and ecotoxicological statuses to provide a global health status.

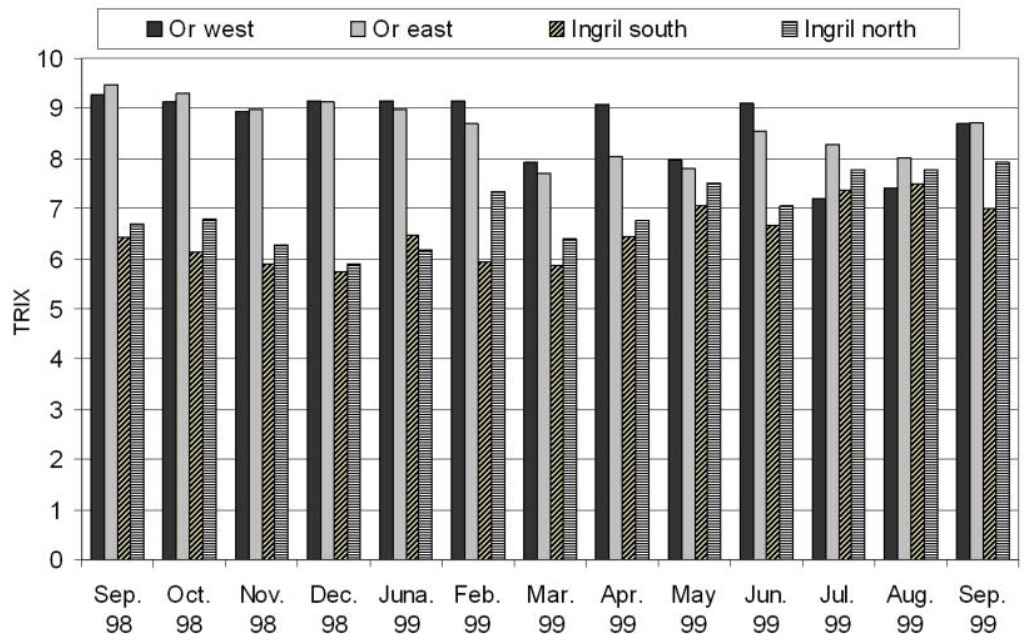

Fig 2. Results of the TRIX test carried out on the 'Ingril' and 'Or' lagoons (Vollenweider, 1998 ) in 1998 and 1999 at two stations in each of the lagoons (West and East for 'Or'; north and south for 'Ingril'), showing that the 'Ingril' lagoon was less eutrophicated than the 'Or' lagoon. The TRIX test is based mainly on the concentration of Chlorophyll-a and oxygen saturation, but also includes values for total nitrogen and phosphorus. 


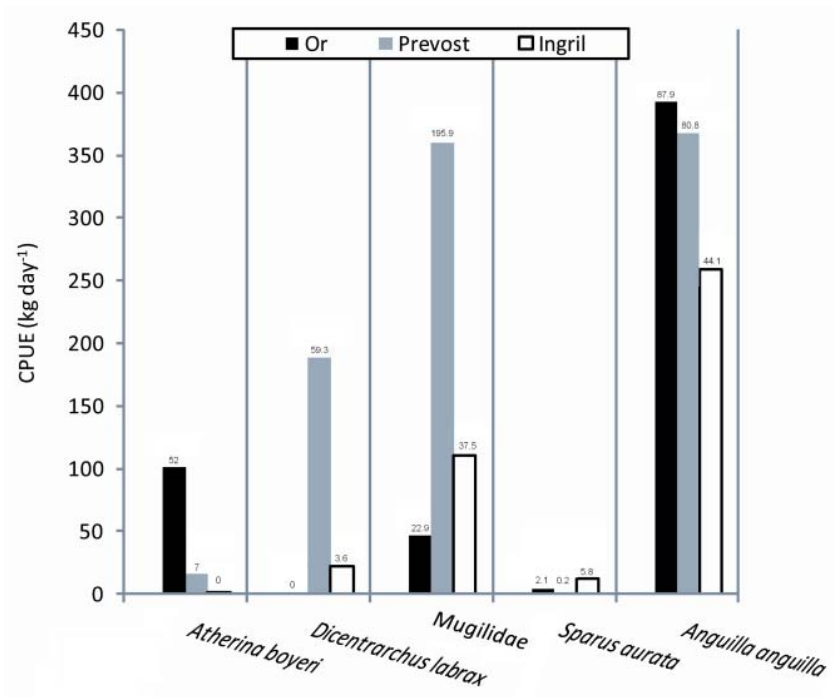

Fig. 3. Catch Per Unit of Effort 'CPUE' scores (in $\mathrm{kg} \mathrm{day}^{-1}$ ) with their standard deviation obtained during the 1999 fishing surveys. The 'Or' lagoon is shown in grey, the 'Prévost' lagoon in black and the 'Ingril' lagoon in white.
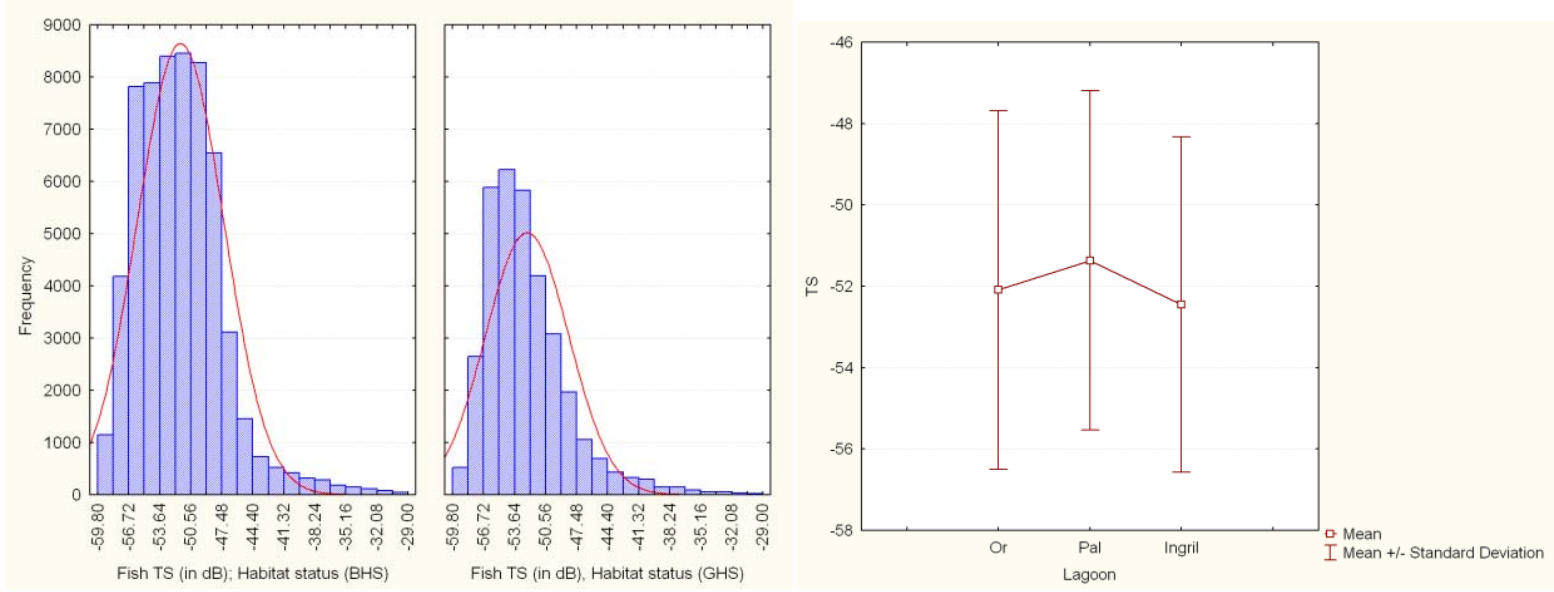

Fig. 4. (a) Plot of mean fish Target Strength values (in $\mathrm{dB}$ ), with \pm standard deviation, observed in the three lagoons. (b) TS distribution, classified by habitat status, of the fish detected in the three lagoons during the three diel legs in each lagoon. A non-parametric test (test U Mann-Whitney) on the acoustic target strength 'TS' distribution with 2 modalities (GHS 'Good Health Statut' clustering Or and Prevost lagoons, or BHS 'Bad Health Statut') revealed a significant difference $(p<0.05)$ between them. 